\title{
LATIN AMERICAN JOURNALS AND HEGEMONIC LANGUAGES FOR ACADEMIC PUBLISHING IN SCOPUS AND WEB OF SCIENCE
}

\section{REVISTAS LATINO-AMERICANAS E LÍNGUAS HEGEMÔNICAS PARA PUBLICAÇÃO ACADÊMICA NO SCOPUS E WEB OF SCIENCE}

\author{
Lucía Céspedes*
}

\section{ABSTRACT}

This paper presents a descriptive analysis of SCOPUS' and Web of Science's journal lists, in order to illustrate and critically assess the current presence of Latin American journals included in these mainstream databases and their working languages for publication. The latest lists of journals released by both databases as of March 2020 were analyzed in terms of journal language and country of publication. Results show Brazil clearly emerges as the regional leader, especially in WoS' Science Citation Index Expanded and Emerging Sources Citation Index. However, this predominance of Brazilian journals does not entail a corresponding relevance of the Portuguese language. Spanish is the predominant language in mainstream Latin American journals, especially in the Social Sciences and Humanities, while journals identified as multilingual tend to associate either Spanish or Portuguese with English. The combination of Spanish and Portuguese is significantly smaller. This calls for a critical revision of the state of the Latin American scientific-editorial field as a linguistic market, as well as for further questioning the role of English as the lingua franca of academia.

Keywords: linguistic market; Latin American scientific field; English as lingua franca

\section{RESUMO}

Este artigo apresenta uma análise descritiva das listas de revistas do SCOPUS e do Web of Science (WoS), a fim de ilustrar e avaliar criticamente a presença atual de revistas latino-americanas incluídas nesses bancos de dados e seus idiomas de trabalho para publicação. As últimas listas de revistas divulgadas pelos dois bancos de dados em março de 2020 foram analisadas em termos de idioma e país de publicação. Os resultados mostram que o Brasil emerge claramente como líder regional, especialmente no Science Citation Index Expanded e em Emerging Sources Citation Index do WoS. No entanto, esse predomínio de revistas brasileiras não implica uma relevância correspondente da língua portuguesa. O espanhol é o idioma predominante nas principais revistas latino-americanas, especialmente nas ciências sociais e humanas, enquanto as revistas identificadas como multilíngues tendem a associar espanhol ou português ao inglês. A combinação de espanhol e português é significativamente menor. Isso exige uma revisão crítica do estado do campo científico-editorial latino-americano como um mercado linguístico, além de questionar ainda mais o papel do inglês como língua franca da academia.

Palavras-chave: mercado linguístico; campo científico latino-americano; inglês como língua franca

\section{INTRODUCTION}

Within social studies of science and technology, there is consensus around the fact that global geopolitical conditions can strongly influence (if not determine) the state and development of local, national, and regional scientific fields (BENNETT, 2014b). Acknowledging this, efforts have been made towards recognizing all knowledge (scientific or otherwise) as situated, whether it comes from the Global North or South (HARAWAY, 2004; HARDING, 2008). Hence, power relations which crisscross scientific fields can be approached from several angles, attending to the geopolitical constraints according to their central, semiperipheral, or peripheral position the within world-system, which has historically been a major concern for Latin American currents of thought (BEIGEL, 2016; KREIMER, 2019). The productivity of these analytical categories derived from world-systems theory (as originally posed by Wallerstein [2004] and further developed by scholars such as de Sousa Santos [1985], Arrighi [1990], or ChaseDunn [1998]) to analyze structural factors of the scientific field worldwide has been asserted by numerous authors (CANAGARAJAH, 2002; BENNETT, 2014b; BEIGEL, 2016; DELVENNE \& KREIMER, 2017; CORCORAN et al., 2019; KREIMER, 2019). These concepts are under constant revision: just as scientific practices are everchanging, the categories used to explain them also become more complex and nuanced.

In this sense, analogous to the world-system, a world scientific system (WSS) is deployed. In spite of clear structural differences among regions and disciplines, the values of the scientific field and what constitutes a successful academic trajectory are becoming increasingly globalized, as the internationalization of sciences turns the field into

\footnotetext{
* Universidad Nacional de Córdoba (UNC), Córdoba, Argentina. lucia.cespedes@unc.edu.ar Orcid: https://orcid.org/0000-0001-5896-3377
} 
an "epistemologically shared universe" and scholars are seen (and see themselves) as international professionals (VESSURI, 2013). Its dynamics, according to Beigel (2014a), are built on three factors: the universal acceptance of bibliometry as a performance evaluation tool, the hegemony of English, and the concentration of academic capital in certain disciplinary areas. As the author describes it, legitimate scientific knowledge circulates within WSS under the form of publications through different circuits, which act as instances of consecration at different levels:

(a) mainstream publishing circuits, sustained by major private enterprises and publishing houses (Thomson Reuters, Elsevier); (b) open access transnational networks and repositories (DOAJ, Dial-net, INASP) created as an alternative to the previous (c) regional Southern circuits (LATINDEX, SCIELO, CLACSO, REDALYC, AJOL); and (d) national circuits based on local publications. These four circuits all come into play in national scientific fields and are relatively segmented, as the result of the uneven distribution of cultural and linguistic capital among scientists, structural constraints and local histories of professionalization/internationalization. (BEIGEL, 2014a, p.745)

As a consequence of these conditions of international production and circulation of knowledge, semiperipheral scientific and academic fields exhibit strong internal tensions. The intermediate category of semiperiphery has received considerable attention in recent decades since it helps reformulate the rigid center/periphery dichotomy. Bennett (2014) describes semiperipheries as a "middle class" or "second tier players", not as deprived as the peripheries of WSS, but with considerably less resources and more economic and institutional hurdles than the centers. Due to their intermediate position, scientific institutions such as universities or research facilities located in semiperipheries often act as regional hubs of knowledge dissemination, thus bridging the gap between the hegemonic epistemologies dominant in the centers and the less constrained models which can flourish in peripheries, "simultaneously sanctioning the values emanating from the centre while refreshing it with new perspectives" (BENNETT, 2014, p.3).

This scenario corresponds more closely to what Salager-Meyer sees as an "increasingly multipolar scientific world in which the distribution of scientific activity is concentrated in a number of interconnected and widely dispersed hubs" (2014, p.78), albeit entangled in unequal power relations. This configures a spectrum of interactions where the linguistic aspect becomes crucial. However, there is more to linguistic struggles than mere language choice. Following Bourdieu (1991), each social field can be seen as a linguistic market, where agents place their products (in the form of oral or written interventions) driven by the anticipation of profit (symbolic, mainly, but material as well) if adjusted to the dominant, legitimate norm. Conversely, (self) recognition of a deviation from the norm will spur agents to apply all sorts of compensation strategies to minimize adverse costs. The scientific field is no exception: scientific capital is accumulated by generating written texts (most often, research articles) according to shared acceptability criteria.

In this sense, it becomes necessary to further problematize the category of English as a lingua franca, widely used to refer to English's allegedly universal standing and linguistic norm in the scientific linguistic market. As Salager-Meyer states, "Because over $85 \%$ of the world's population lives in the 153 countries categorized as lowand/or middle-income countries, we can easily assert that there is a world of publishing that does not operate in English or emanate from English-speaking countries" (2014, p.79). In his historical reconstruction of the concept, Gordin (2005) points out that, originally, the lingua franca was an actor's category used to refer to a simplified variety of some Romance languages, used by merchants in the Mediterranean area during the Late Middle Ages and up to the early Modern Age. Lingua franca eventually became a theoretical term within Linguistics to denote any language (not necessarily a simplified version) whose use extends over the (always fuzzy) boundaries of different linguistic communities (VIKØR, 2004). This is to say, nowadays, lingua franca as a category not only encompasses non-standard linguistic varieties, with no native speakers of their own, born as contact languages; it also applies to standard languages which have native speakers and different degrees of prestige, adopted for communicative purposes among speakers of different languages. English, therefore, may act as a de facto lingua franca, albeit not a symmetric one: it is the national language of the main hegemonic centers in the world-system, and the native language of some of the most influential agents in the global scientific field (AMMON, 2012).

In an increasingly interconnected scientific field, the use of English as the linguistic norm for research and publication purposes (ERPP) is widely debated. When we consider, with Bourdieu, that linguistic struggles are never exclusively about language itself, the way language can reveal reproduction mechanisms or subversion strategies of established power structures becomes clearer. In this line, Curry and Lillis agree that "Multilingual scholars therefore enter the academic publishing 'game' on a 'field' that is not level, both in terms of access to English as well as to other social and material resources (research and travel funding, library access) needed for publication" (2014, p.5). Bennett (2014b) does not fail to mention the linguistic and rhetorical hindrances stemming from the hegemony of 
English in academic publishing, but she also highlights the non-linguistic barriers such as unequal access to resources and scholarly networks, and institutional or infrastructural deficiencies. Hultgren (2019) emphasizes access to material resources and networks as more significant factors than linguistics to explain the undeniable inequity and comparative privilege in global knowledge production and academic publication.

As these criteria become increasingly globalized and incorporated in the form of scientific babitus, in bourdieusian terms (SALÖ, 2015), the pressure to publish, publish first, and publish in high-impact, strategic outlets, weigh equally over researchers worldwide (in spite of the unequal distribution of publication opportunities and resources). Currently, in the mainstream circuit, it is certain databases that define which are significant publications, this is, those of top scientific quality and greater symbolic capital. The two most prestigious databases (also the most cited, the ones that carry top scores in many institutional or individual performance assessments, and the most used in bibliometric and scientometric studies) are Web of Science (WoS), property of Clarivate Analytics, and SCOPUS, property of Elsevier. The overrepresentation of journals in English in such databases is well documented (AMMON, 2012; HAMEL, 2013; CURRY \& LILLIS, 2014; VESSURI et al., 2014; ENGLANDER, 2014), and while the linguistic aspects and implications of these conditions of science production and circulation are well researched for Europe (MORENO FERNÁNDEZ et al., 2012; BOCANEGRA-VALLE, 2013; SALÖ, 2015) and some Asian countries (FLOWERDEW, 2007; HANAUER et al., 2019), Latin America is underrepresented in the available literature for the topic, as Curry and Lillis (2017) and Monteiro and Hirano (2020) have noted.

The growing importance of choosing the "right" publication outlet and writing in the "right" language raises questions about the options Latin American scholars have for international publishing, considering that most performance evaluation criteria worldwide increasingly take into account publications in "international" journals as one of the most important indicators. However, as Curry and Lillis (2014) have observed, in recent decades the signifier "international" has slid towards the signifier "English", and together, both terms constitute a naturalized - but by no means natural- indicator of scientific quality. As Solovova et al. have asked, "Are there prestigious and valued spaces available for publishing research in other languages besides English?" (2018, p.2)

Therefore, in this paper, I present a descriptive analysis of SCOPUS' and Web of Science's journal lists as per their last updates. While bearing in mind the critiques discussed earlier, we agree with O'Neill in that, given the current conditions and "rules of the game" within WSS, "a country's publication rate in scientific journals (...) is nevertheless a useful estimate of its participation in the global scientific community" (2018, p.150). Therefore, I aim to illustrate and critically assess the current presence of Latin American journals in the two most prominent mainstream databases, and their working languages for publication. Based on this synchronic study, I will argue in favor of the practice of publishing and improving high-quality academic journals which do not instantly relegate national languages in favor of English as a way of strengthening national scientific systems in semiperipheral and peripheral regions and of fostering South-South constructive relations and cooperation. At the same time, I reflect on the role of English as the lingua franca of science (a category often used rather uncritically, without much consideration of the historical contingency of such a position), and its consequences on the trajectories of multilingual peripheral scientists.

\section{DATA ANALYSIS METHODOLOGY}

The data for this research was extracted from the Master Journal List (MJL) from the Web of Science Core Collection, which comprises the Science Citation Index Expanded (SCIE), the Social Sciences Citation Index (SSCI), the Arts \& Humanities Citation Index (AHCI), and the Emerging Sources Citation Index (ESCI), as available on Clarivate Analytics' official website as of March 2020 (the List was last updated February 2020). However, the downloadable Microsoft Excel files for each collection list only include the journal title, ISSN/eISSN, publisher name and address. Since my interest lies on journals' languages and countries, I produced my own tables via a manual search with the website's "Search Journal" engine. In this way, I first quantified journals included in each of the four WoS Core Collection indexes by language and country of publication. I then focused on Latin American (including the Caribbean) countries, once again analyzing journals per country and language of publication. A total of 21,226 journals were scanned for language and country of publication. Besides scrutinizing each index separately, I also examined WoS as a whole. Since some journals are included in more than one of the WoS Core Collection indexes 
(overlapping is common in SCCI and AHCI), the sum of SCIE, SSCI, AHCI and ESCI totals is higher than the net total of journals in WoS, in which case I eliminated such double entries.

The same method was applied for the Scopus Source List. Downloaded from Scopus' official website in March 2020 and last updated in September 2019, the Source List is also presented as a downloadable Microsoft Excel file. Only 25,185 journals out of the 39,743 indexed in the Source List are classified as Active; therefore, I took that sample for my analysis. Whereas WoS allows for a broad disciplinary distinction which is highly relevant to the observation of linguistic trends within the WSS, Scopus indicates the several languages in which multilingual journals are published (as opposed to WoS, which only categorizes them as "Multi-language"). This in turn allows for the observance of trends in language choice, precisely my main concern as regards the Latin American scientific field. All tables and figures were generated with Microsoft Excel and, unless indicated otherwise, are the author's own elaboration.

\section{RESULTS}

At present, 40 different languages are represented among the 25,185 active journals indexed in SCOPUS; however, 19,873 (78.9\%) of them are published in English only (including journals from non-Anglophone countries). WoS' four MJL indexes cover a total of 41 languages in 21,226 journals, 13,075 (62\%) of which only accept works in English. This disproportionate linguistic concentration has its geopolitical counterpart: $48 \%$ of journals indexed in SCOPUS and 49\% of those in WoS are American or British. As can be seen in Table 1, WoS has a very high percentage of unclassified journals, or journals for which data is not provided as regards language of publication. Figures for both English and other languages could be expected to increase if this categorization were more accurate. The inclusion of Catalan and Croatian in WoS' top ten languages can be attributed to the indexing of a considerable number of journals published in these languages in ESCI, where journals are included while being considered for SCIE, SCCI and/or AHCI.

Table 1. Top ten languages and countries of publication in SCOPUS and WoS, in number of journals (N) and percentages.

\begin{tabular}{|c|c|c|c|c|c|}
\hline \multicolumn{5}{|c|}{ Journals by language } & \multirow[b]{2}{*}{$\%$} \\
\hline SCOPUS & $\mathrm{N}$ & $\%$ & WoS & $\mathrm{N}$ & \\
\hline English & 19873 & 78.9 & English & 13075 & 62 \\
\hline Multi-language & 2073 & 8.2 & No data & 6271 & 30 \\
\hline No data & 595 & 2.4 & Multi-language & 729 & 3.4 \\
\hline Spanish & 579 & 2.3 & Spanish & 394 & 1.9 \\
\hline Chinese & 366 & 1.5 & Portuguese & 180 & 0.8 \\
\hline German & 339 & 1.3 & German & 116 & 0.5 \\
\hline French & 286 & 1.1 & French & 104 & 0.5 \\
\hline Portuguese & 176 & 0.7 & Catalan & 62 & 0.3 \\
\hline Russian & 162 & 0.6 & Russian & 40 & 0.2 \\
\hline Italian & 143 & 0.6 & Croatian & 39 & 0.2 \\
\hline \multicolumn{6}{|c|}{ Journals by country of publication } \\
\hline SCOPUS & $\mathrm{N}$ & $\%$ & WoS & $\mathrm{N}$ & $\%$ \\
\hline United States & 6247 & 25 & United States & 5789 & 27 \\
\hline United Kingdom & 5828 & 23 & United Kingdom & 4663 & 22 \\
\hline Netherlands & 2313 & 9.2 & Netherlands & 1323 & 6.2 \\
\hline Germany & 1717 & 6.8 & Germany & 1118 & 5.3 \\
\hline Switzerland & 686 & 2.7 & Spain & 743 & 3.5 \\
\hline Spain & 589 & 2.3 & Switzerland & 521 & 2.5 \\
\hline China & 574 & 2.3 & Italy & 447 & 2.1 \\
\hline
\end{tabular}




\begin{tabular}{ccc|ccc} 
France & 505 & 2 & Brazil & 415 & 2 \\
Italy & 488 & 1.9 & Poland & 383 & 1.8 \\
Russia & 472 & 1.9 & France & 381 & 1.8 \\
\hline
\end{tabular}

Latin America boasts a total of 833 journals in SCOPUS (a meagre 3.3\% of the index's total) and 1,048 (4.9\%) in WoS. Notably, this latter figure falls to 278 if ESCI is not included, which makes ESCI the main WoS index in which Latin American journals are included (see Table 2).

Table 2. Latin American journals in SCOPUS and the four WoS Master Journal List indexes.

\begin{tabular}{lcc}
\hline & Number of journals & \% in relation to index total \\
\hline SCOPUS & 833 & 3.3 \\
WoS (total) & 1048 & 4.9 \\
WoS SCIE & 194 & 2 \\
WoS SCCI & 59 & 1.7 \\
WoS AHCI & 40 & 2.2 \\
WoS ESCI & 770 & 10.1 \\
\hline
\end{tabular}

Both in SCOPUS and WoS, Brazil widely surpasses the rest of Latin America, as can be observed in Table 3. Brazil accounts for $45.3 \%$ of Latin American academic journals indexed in SCOPUS, and for $40 \%$ of those in the four indexes which comprise WoS' MJL taken jointly. This puts the country in a leading position in the creation (and, we should also highlight, the maintenance) of journals which meet the requirements of the mainstream publication circuit. Macroeconomic indicators are also given as reference.

Table 3: Latin American journals in WoS and SCOPUS, in number of journals $(\mathrm{N})$ and percentages; Gross Domestic Expenditure on R\&D (GERD) in million USD at Purchase Power Parity (PPP); and GERD as a percentage of Gross Domestic Product (GDP) (2018 or last available data) (RICyT, 2019; OECD, 2020).

\begin{tabular}{|c|c|c|c|c|c|c|}
\hline & \multicolumn{2}{|c|}{ WoS } & \multicolumn{2}{|c|}{ SCOPUS } & \multirow[t]{2}{*}{ GERD } & \multirow{2}{*}{$\begin{array}{c}\text { GERD as percentage of } \\
\text { GDP }\end{array}$} \\
\hline & $\mathrm{N}$ & $\%$ & $\mathrm{~N}$ & $\%$ & & \\
\hline Argentina & 100 & 9.5 & 62 & 7.4 & 4971.3 & 0.54 \\
\hline Bolivia & 2 & 0.2 & - & - & 70.88 & 0.16 \\
\hline Brazil & 415 & 40 & 377 & 45 & 41128.76 & 1.26 \\
\hline Chile & 97 & 9.3 & 100 & 12 & 1556.4 & 0.36 \\
\hline Colombia & 188 & 18 & 111 & 13 & 1714.11 & 0.24 \\
\hline Costa Rica & 27 & 2.6 & 4 & 0.5 & 357.69 & 0.43 \\
\hline Cuba & 20 & 1.9 & 21 & 2.5 & 417.1 & 0.43 \\
\hline Dominican Republic & 1 & 0.1 & - & - & $\mathrm{N} / \mathrm{D}$ & $\mathrm{N} / \mathrm{D}$ \\
\hline Ecuador & 17 & 1.6 & 2 & 0.2 & 809.9 & 0.44 \\
\hline El Salvador & 1 & 0.1 & - & - & 92.92 & 0.18 \\
\hline Jamaica & 1 & 0.1 & 4 & 0.5 & $\mathrm{~N} / \mathrm{D}$ & $\mathrm{N} / \mathrm{D}$ \\
\hline Mexico & 95 & 9.1 & 109 & 13 & 8053.9 & 0.31 \\
\hline Nicaragua & 2 & 0.2 & - & - & $\mathrm{N} / \mathrm{D}$ & $\mathrm{N} / \mathrm{D}$ \\
\hline Paraguay & 2 & 0.2 & - & - & 132.02 & 0.15 \\
\hline Peru & 22 & 2.1 & 9 & 1.1 & 522.25 & 0.12 \\
\hline Puerto Rico & - & - & 3 & 0.4 & 561.85 & 0.43 \\
\hline Trinidad and Tobago & 1 & 0.1 & - & - & 40.19 & 0.09 \\
\hline Uruguay & 14 & 1.3 & 1 & 0.1 & 380.52 & 0.49 \\
\hline Venezuela & 43 & 4.1 & 30 & 3.6 & 3363.54 & 0.69 \\
\hline TOTAL & 1048 & 100 & 833 & 100 & & \\
\hline
\end{tabular}


It should be noted that, if we disaggregate WoS into its four indexes, Brazil's supremacy can be attributed mainly to the vastly superior number of Brazilian journals indexed in SCIE and ESCI. In SCCI, Brazil, Chile and Mexico are practically at par, while Chile even overtakes Brazil in AHCI (see Figure 1). Remarkably, every Latin American country (except Chile) exhibits a greater proportion of journals included in ESCI than in the other three WoS indexes combined.

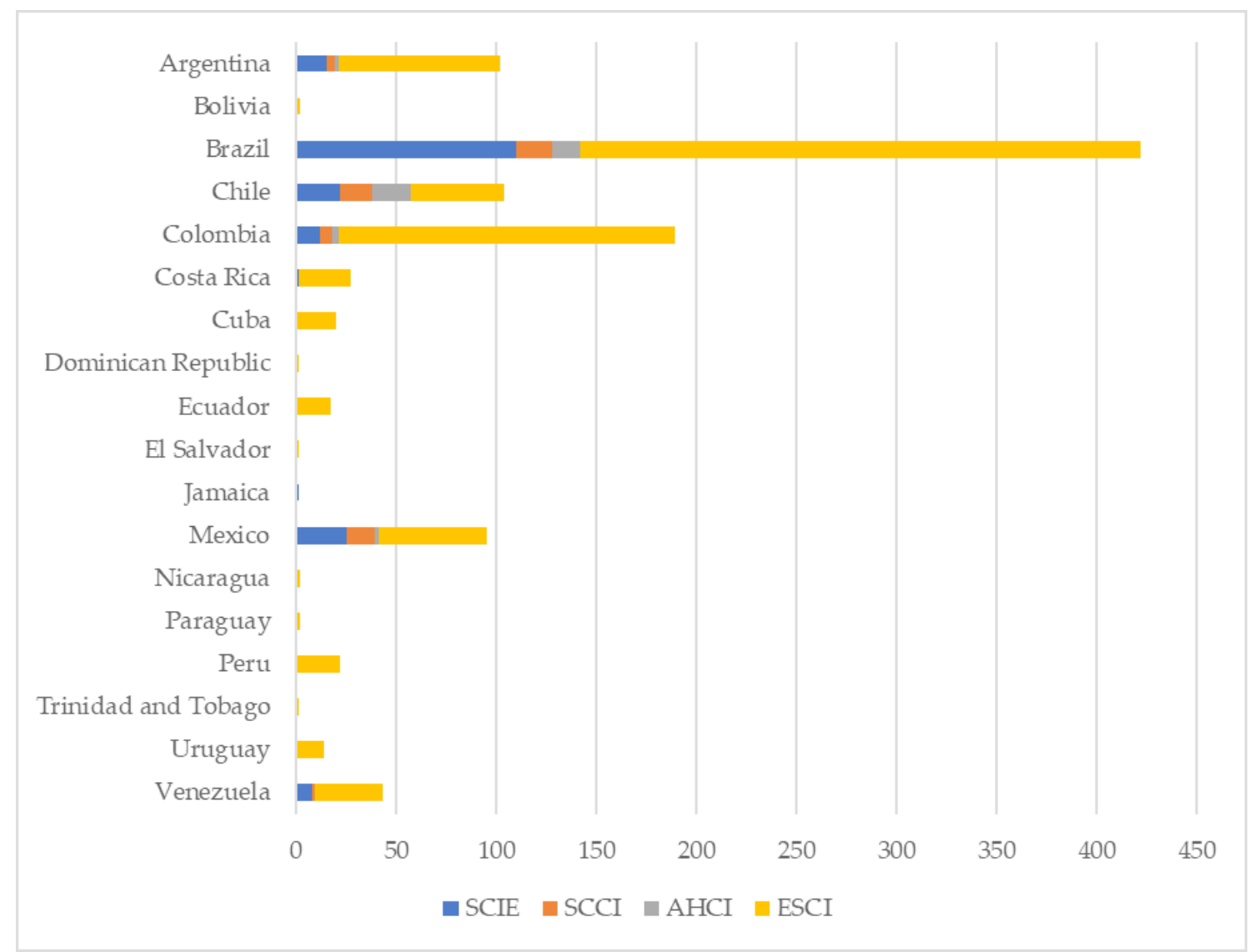

Figure 1. Number of Latin American journals included in each of the four WoS MJL indexes, by country of publication

The predominance of Brazilian publications does not entail a corresponding relevance for the Portuguese language. Of all Latin American journals in SCOPUS, there are 148 published exclusively in this language, representing $18 \%$ of the total. In contrast, 266 journals (32\%) are in Spanish. Moreover, 112 journals (13\%) are published in English only. Furthermore, in SCOPUS, 278 (33\%) Latin American journals are classified as multilanguage, this is to say, they accept papers in two or more languages. 369 (35\%) of Latin American journals indexed in WoS are published in English only, while 228 (22\%) are published in Spanish, 168 (16\%) in Portuguese, 21 (2\%) are multi-language and 8 (less than 1\%) are published in other languages. It should be noted, however, that WoS exhibits a large percentage of journals for which no data is provided as regards language of publication (Figure 2). 


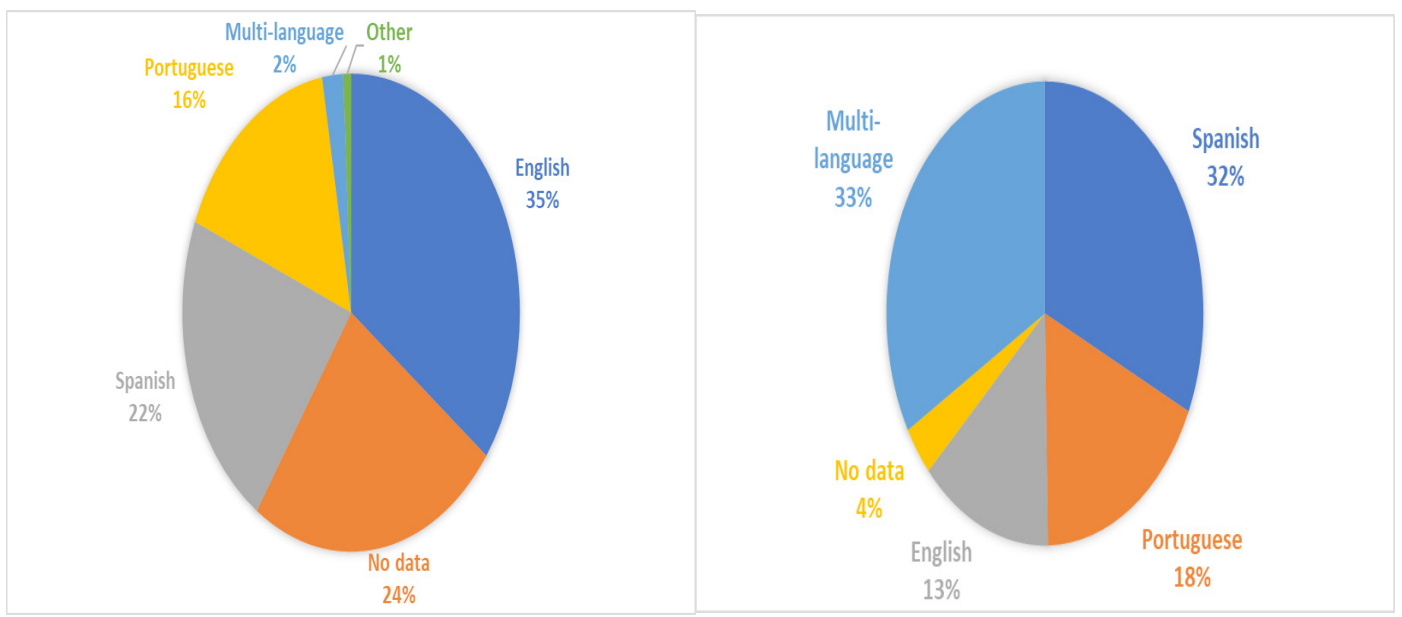

(a)

(b)

Figure 2. (a) Languages of publication of Latin American journals included in WoS; (b) Languages of publication of Latin American journals included in SCOPUS.

As Table 4 shows, the combination of Spanish and Portuguese is a minority among the 278 multi-language Latin American journals in SCOPUS. The main linguistic combination is Spanish and English, with 111 journals (40\%). Portuguese and English come next with 92 (33\%), while Spanish and Portuguese come together in 26 journals (9\%). Other $34(12 \%)$ add English as a third language for article submission. Thus, the term "multi-language" (as a category to classify journals) results little more than a euphemism to signify "major/official language in the country of publication + English".

Table 4. Number and percentage of multi-language Latin American journals in SCOPUS by combination of languages

\begin{tabular}{lcc}
\hline \multicolumn{1}{c}{ Languages } & N of journals & $\%$ \\
\hline Eng-Spa & 111 & 40 \\
Eng-Por & 92 & 33 \\
Eng-Spa-Por & 34 & 12 \\
Spa-Por & 26 & 9 \\
Other & 15 & 5 \\
\hline TOTAL & 278 & 100 \\
\hline
\end{tabular}

Finally, this linguistic phenomenon is also closely linked to the specificity of each discipline. Since WoS offers different indexes according to broad disciplinary divides, we are able to see that, in SCIE, 52.6\% of Latin American journals publish articles exclusively in English (Table 5). The percentage of Latin American journals published only in English falls to $22.5 \%$ in AHCI, and to an even lower 19\% in SCCI. ESCI is a particular case, given that, according to the data provided by WoS, 32.6\% of Latin American journals indexed there are published in English only, 20.6\% in Spanish, and 15.2\% in Portuguese. However, once again, the fact that as much as 31.6\% of the journals included in this index are classified under "Other/Not provided", and that no journal appears as "Multi-language", raises doubts about the reliability of this data. The same applies for $\mathrm{AHCl}$, where 16 journals representing $40 \%$ of Latin America's total in this index are unclassified for language. 
Table 5. Latin American journals by language of publication in each of the four WoS Master Journal List indexes, in number of journals (N) and percentages

\begin{tabular}{lrrrrrrrr}
\hline & \multicolumn{2}{c}{ SCIE } & \multicolumn{2}{c}{ SCCI } & \multicolumn{2}{c}{ AHCI } & \multicolumn{2}{c}{ ESCI } \\
\hline Spanish & $\mathrm{N}$ & $\%$ & $\mathrm{~N}$ & $\%$ & $\mathrm{~N}$ & $\%$ & $\mathrm{~N}$ & $\%$ \\
Portuguese & 33 & 17 & 32 & 54 & 11 & 27.5 & 159 & 20.6 \\
English & 38 & 19.6 & 13 & 22 & 3 & 7.5 & 117 & 15.2 \\
Multi-language & 102 & 52.6 & 11 & 19 & 9 & 22.5 & 251 & 32.6 \\
Other/No data & 19 & 9.8 & 2 & 3.3 & 1 & 2.5 & - & - \\
Total & 2 & 1 & 1 & 1.7 & 16 & 40 & 243 & 31.6 \\
\hline
\end{tabular}

\section{DISCUSSION}

This study reveals that, even within Latin American journals inserted in the mainstream publication/ consecration circuit (a priori, those of top-quality research and with a global reach, but see Beigel [2014b, p.745], and Gruber [2014, p.167]), English appears as a complement to Spanish and Portuguese, but not yet reaching the level of penetration reported in other linguistic and regional contexts (AMMON, 2012; SALÖ, 2015; SOLOVOVA et al., 2018). While marginal, as shown by the scarce percentage of Latin American journals in relation to the indexes' totals, languages other than English do have a presence in the international mainstream circuit. In this sense, Ortiz $(1997,2009)$ and Lillis et al. (2010) have observed that emphasis on the neutrality of English as an academic lingua franca often implies an uncritically positive valuation of this language's role, while masking the differential and unequal conditions under which scientific texts are written, published, and evaluated in centers and peripheries. All things considered, my results tend to show Spanish still stands as the predominant language for journals published in Latin America, especially in journals devoted to the Social Sciences and Humanities. Hence, I agree with Gordin (2015) when he speaks of "hegemonic languages" rather than linguas francas throughout the history of sciences: Latin, Arabic, Italian, French, German, Russian, and, currently, English, all held that position in different historic conjunctures and to different degrees. In the case of Spanish and Portuguese, these are indeed hegemonic languages within Latin America with reminiscences of conquest, coloniality, and the linguistic subjugation of native languages and communities. Language choice, then, "is situated in a multilayered history of power relations" (SOLOVOVA et al., 2018, p.4). For multilingual scientists (located in centers, semiperipheries, and peripheries), this choice is often

made for them, when they are coerced by institutional policies that require or overwhelmingly incentivize publication in Englishlanguage journals (...) These policies are based on 'underlying structures of power and prestige' (Breeze, 2015: 40) that strip linguistic agency from individual scholars and inflict unintended costs on 'national' journals, which may suffer a loss of status and even viability due to the privileging of English as the language of 'international' discourse (O’NEILL, 2018, p.149).

Linguistic tendencies and language choice can also be analyzed in terms of disciplines. As seen in Table 4 of the Results, more than half of Latin American journals indexed in WoS' SCIE publish articles in English only. As I have stated, in this particular index Brazil widely surpasses the rest of Latin American countries in number of journals. This allows for a double interpretation: only in this index does Portuguese surpass Spanish as language of publication, which may be attributed to the sheer volume of the Brazilian editorial field. But this also positions the Brazilian hard sciences as one of the driving forces towards the adoption of English as the language of choice for publication purposes among Latin American mainstream journals. This is consistent with Monteiro and Hirano's (2020) recent study, which shows that Brazilian researchers in the hard sciences prefer publishing in English in international, mainstream journals, and report fewer challenges doing so than their colleagues in the Social Sciences and Humanities. As regards Latin American journals indexed in a mainstream database such as WoS, it is precisely among these more culturally, linguistically embedded disciplines (BENNETT, 2015), where context plays a major role in the defining of scholarly traditions and language is an active constituent of knowledge, paradigms, objects of study, and methodologies (ORTIZ, 2009; SOLOVOVA et al., 2018), that Spanish and Portuguese exhibit a greater prevalence than English. 
The results for ESCI are particularly interesting. Remarkably, every Latin American country (except Chile) exhibits a greater proportion of journals included in ESCI than in the other three WoS indexes combined. Three clear groups can be established. Behind the gigantic Brazil, Argentina, Chile, Mexico, and Colombia are the regional leaders in this index. A second group would be comprised of Venezuela, Costa Rica, Peru, Cuba, Ecuador, and Uruguay, countries which at the moment have little to no presence in SCIE, SCCI, and AHCI, but do hold some 34 to 14 journals in ESCI. Finally, a third group would include Bolivia, Nicaragua, Paraguay, Dominican Republic, El Salvador, and Trinidad and Tobago. These are some of the most relegated countries in the region, where investment in science and $\mathrm{R} \& \mathrm{D}$ is also the lowest (as shown in Table 3), but which nevertheless are taking their first steps in placing their own scientific journals in these dominant, prestigious databases. Coincidentally, these three profiles could very well be identifying regional scientific centers, semi-peripheries, and peripheries in terms of academic publishing.

This reveals a significant effort on the part of Latin American scientific institutions to publish and maintain high-quality journals, with the perspective of eventually having them included in SCIE, SCCI, and/or AHCI. This is no small feat bearing in mind that, as Fischman et al. (2010) have reported, public, state-funded universities are the main editors of scientific journals in Latin America, which are often riddled by institutional and budgetry issues. Those Latin American journals that do make it into mainstream indexes gain in terms of prestige and symbolic capital, but they enter a game in which they compete against much better endowed players: mainstream journals published in traditional scientific centers are mainly published by transnational editorial groups (FISCHMAN et al., 2010). The matter is by no means limited to Latin America: a recent study by Bocanegra-Valle (2019) in Spain shows that insufficient institutional support and poor funding are some of the main weaknesses of that country's academic journals as perceived by national scholars. Salager-Meyer $(2014,2015)$ has also repeatedly pointed at shortage of financial resources and poor institutional infrastructure as some of the main issues peripheral journals face.

In terms of financial support to scientific institutions, Brazil's position as the leader in academic publishing within Latin America does have a certain correlation with investment in its national scientific system. The IberoAmerican and Interamerican Network of Science and Technology Indicators (RICyT, by its Spanish acronym) latest study (2019) adds that, as of 2017, 86\% of Latin America's R\&D investment was concentrated in three countries: Brazil (65\%), Mexico (13\%) and Argentina (8\%). Far behind came Colombia (3\%) and Chile (2\%). This could be attributed to the volume of each country's economies, as shown in Table 3, Brazil's GERD as a percentage of GDP is also the highest in Latin America. This tendency is confirmed by looking at the volume of national scientific communities: Brazil triples Argentina in sheer number of full-time researchers, postdoctoral and doctoral students. Next comes Mexico and, on a smaller scale, countries such as Chile, Venezuela, Ecuador, and Colombia (RICyT, 2019). This coincides with the grouping I drew previously when analyzing Latin American journals included in ESCI. In this sense, the concept of nesting as put forward by Chase-Dunn (1998) might be useful: the author shows how inequities derived from the core-semiperiphery-periphery hierarchy are nested within regional blocs, and inside nation states themselves. The patterns of investment in science and, to a certain extent, the patterns of scientific mainstream journal publishing, both speak of a strong concentration of scientific and editorial activity in a few subregional centers.

However, the efforts of Mexico and Argentina, two of the leading scientific countries in the region behind Brazil, do not translate into a corresponding leadership in the publishing of top-tier academic journals. On the contrary, Colombia and Chile, two countries with less GERD, lower percentages of GERD in relation to GDP, and smaller scientific communities, exhibit a comparatively higher mainstream editorial activity. Since nested hierarchies are historically dynamic and multi-layered, it is possible that countries with a priori stronger research traditions and national scientific systems, this is, the regional scientific centers, are not necessarily central in terms of the edition and publication of mainstream academic journals. We could then conceive of publishing, research, and language as three interconnected avenues that need to be taken into account jointly in order to give an accurate, balanced evaluation of national or regional scientific fields within the World Scientific System. Judging by the results of this research, these three factors may not be given the same priority in terms of scientific policy.

If, as I have shown, sciences around the world are carried out in multiple languages, monolingualism still prevails in Anglophone centers: half of journals in the two databases studied are published in the USA or UK, and in English only. This contributes to the invisibilization of scientific work published in languages other than English, precisely in those core areas where the global rules of the game are established (CURRY \& LILLIS, 2014; VESSURI et al., 2014). 
Inequalities imposed by world-system hierarchies notwithstanding, it would be reductionist to place peripheral and semiperipheral countries in a merely receptive and passive role facing the dominance from core areas. Among others, Beigel $(2014 a, 2014 b, 2016,2017)$ rejects this oversimplification since it would mean not acknowledging the solid trajectory of certain non-mainstream academic traditions and scientific communities. In her view, it is necessary to break away from the stereotype which equates centrality to intellectual autonomy and peripherality to heteronomy. Academic and intellectual peripherality is not manifested by copy or massive acculturation, she claims, but rather by the invisibilization of original thought produced in peripheries. On the contrary, current conditions of circulation, evaluation, and appropriation of knowledge automatically recognize traditional scientific centers as legitimate sources of innovation.

\section{CONCLUSIONS}

By approaching the international scientific field through its linguistic dimension, traditional geopolitical borders between central and (semi)peripheral areas become more complex. In this paper I have reviewed the presence and languages of Latin American scientific journals indexed in WoS and SCOPUS. Brazil clearly emerges as the regional leader in journals accepted by both catalogues, especially in WoS' Science Citation Index Expanded. However, this predominance of Brazilian journals does not entail a corresponding relevance of the Portuguese language. Spanish is the predominant language in mainstream Latin American journals. The combination of Spanish and Portuguese is significantly smaller. Multilingualism is achieved by incorporating English besides one or both of these languages, the two major ones in the region. While Latin American scientists are increasingly being pushed towards publishing in high-impact, mainstream journals, the region still lags behind in terms of editorial initiatives (although, as I have said, an ambition to reach top-tier databases can be inferred from the number of journals already in WoS' ESCI).

The point made in this article, that scientific centers do not necessarily coincide with editorial centers in the region, makes the concepts of scientific-academic centrality and peripherality even more subtle and requiring of more nuanced analyses. Just as O'Neill (2018) has established a strong, statistically significant correlation between a country's GDP and its scientific output measured in number of documents indexed in the Scimago index (which is compiled from Scopus' database), a quantitative analysis of the correlation between GDP, GERD, and the number of journals published by country would be an interesting development in this direction.

One of the main obstacles I faced when preparing this article was the lack of systematized data in terms of metrics and indicators of scientific activity in Latin America. In spite of offering some of the most reliable and comprehensive reports in the area, RICyT currently only offers data up to 2018. It then becomes difficult to assess the editorial and publishing activity of the region against the backdrop of, for instance, its investment in R\&D or the size and composition of its scientific communities. While initiatives such as RICyT's development of handbooks specifically tailored for Ibero-America (JARAMILLO et al., 2001; LUGONES et al., 2009; POLINO \& CASTELFRANCHI, 2015; CASTRO MARTÍNEZ \& CARULLO, 2017) have definitely been a step forward, the systematic production of unified regional scientific activity metrics is still a pendant issue and the need for updated, reliable data on Latin America continues. In this sense, an interesting line of future work could be the reconstruction of Latin American journals' trajectories in the mainstream circulation circuit in order to assess, for example, the period of time elapsed between inclusion in ESCI and the definitive inclusion in either SCIE, SCCI, or AHCI, the percentage of journals which achieve this upgrade and the strategies deployed to do so, and the challenges faced by those which do not. In such a study, identifying the nature of scholarly publishing agents in Latin America would be crucial (commercial editorial enterprises, non-commercial groups, universities, professional associations, among others). This would lead to a more accurate portrayal of the Latin American academic publishing field (or space, as Salatino [2018] has called it).

Going back to Beigel's (2014a, 2014b, 2016, 2017) concept of publication/consecration circuits, we can conceptualize a topography of publication possibilities according to the endowment of scientific and linguistic capital of each agent, their babitus-related representations, and the material-structural conditions of the field in the different national contexts. This would indeed be an interesting line of work for future research, especially if it fosters a critical revision of academic publishing policies (once again bearing in mind how Latin American journals 
are mainly published by national universities) and alternative ways of circulating knowledge and measuring scientific performance and impact (at a regional, national, institutional, and even individual level).

Moreover, during the course of these study I identified numerous gaps in both WoS' and SCOPUS' journal lists, especially, as I have pointed out, in WoS' ESCI. The high percentage of journals listed as "Other/No data" as regards language of publication introduces too great a margin of error and raises questions about the reliability of this data. A random cross-check between the information given by these databases and the websites of a number of journals I am acquainted with even showed gross discrepancies as regards what WoS and SCOPUS inform, and the actual languages accepted by these journals. Given the widespread usage of WoS and SCOPUS for bibliometric studies and research, I cannot help but wonder what the real figures for language of publication would look like if each and every single journal indexed in these databases were correctly and thoroughly categorized.

To conclude, I seek neither to give a romanticized view of local languages, not to demonize the use of English, as Harding (2008) warns regarding the contraposition of scientific, epistemological traditions from the Global North and South. Latin American sciences will not be intrinsically better, more democratic, or more egalitarian just because they are published in its own journals or done or written in Spanish or Portuguese. Far from essentialist perspectives which ascribe an innate superiority for science, drama, or rhetoric to certain languages, I consider the linguistic hegemony of English, Spanish or Portuguese as indebted to the power of institutions capable of imposing universal recognition of the dominant language over the linguistic market (BOURDIEU, 1991). In this aspect, as in many others, the Latin American scientific field is marked by a permanent tension between autonomy and heteronomy derived from its subordinate situation in the World Scientific System and the world-system in general. The linguistic question is only one of the many facets in which this tension manifests itself. I then consider this article as a small contribution to the further development of a sociolinguistic perspective of sciences, in order to deepen our comprehension about current processes of integration or exclusion of non-central, non-Anglophone voices in the scientific world concert.

\section{REFERENCES}

AMMON, U. (2012). Linguistic inequality and its effects on participation in scientific discourse and on global knowledge accumulation - With a closer look at the problems of the second-rank language communities. Applied Linguistics Review, vol. 3, nº 2, pp. 333-355. https://doi.org/10.1515/applirev-2012-0016.

ARRIGHI, G. (1990). The Developmentalist Illusion: A Reconceptualization of the Periphery. In Martin, W. G. (ed.), Semiperipheral States in the World-Economy. New York: Greenwood Press, pp. 11-42.

BEIGEL, F. (2014a). Introduction: Current tensions and trends in the World Scientific System. Current Sociology, vol. 62, n 5, pp. 617-625. https://doi.org/10.1177/0011392114548640

BEIGEL, F. (2014b). Publishing from the periphery: Structural heterogeneity and segmented circuits. The evaluation of scientific publications for tenure in Argentina's CONICET. Current Sociology, vol. 62, n 5, pp. 743-765. https://doi. org/10.1177/0011392114533977

BEIGEL, F. (2016). The Politics of Academic Autonomy in Latin America. New York: Routledge.

BEIGEL, F. (2017). Científicos Periféricos, entre Ariel y Calibán. Saberes Institucionales y Circuitos de Consagración en Argentina: Las Publicaciones de los Investigadores del CONICET. Dados, vol. 60, n ${ }^{\circ} 3$, pp. 825-865. https://doi. org/10.1590/001152582017136

BENNETT, K. (ed). (2014a). The semiperiphery of academic writing: discourses, communities and practices. London: Palgrave Macmillan. https://doi.org/10.1057/9781137351197

BENNETT, K. (2014b). The "Butler" Syndrome: Academic Culture on the Semiperiphery. Revista Canaria de Estudios Ingleses, $\mathrm{n}^{\circ}$ 69, pp. 155-171.

BENNETT, K. (2015). Towards an epistemological monoculture: Mechanisms of epistemicide in European research publication. In: Plo-Alastrué, R. \& Pérez-Llantada, C. (eds.). English as a Scientific and Research Language: Debates and Discourses. Berlin/ Boston: de Gruyter, pp. 9-36. 
BOCANEGRA-VALLE, A. (2013). The perceived value of English for academic publishing among ESP multilingual scholars in Europe. ESP Today, vol. 1, n 1 , pp. 5-25.

BOCANEGRA-VALLE, A. (2019). Building a Reputation in Global Scientific Communication: A SWOT Analysis of Spanish Humanities Journals. Canadian Journal of Sociology, vol. 44, n 1, pp. 39-66.

BOURDIEU, P. (1991). Language and Symbolic Power. Cambridge: Harvard University Press.

CANAGARAJAH, S. (2002). A Geopolitics of Academic Writing. Pittsburgh: Pittsburgh University Press.

CASTRO MARTÍNEZ, E., \& CARULLO, J. C. (coords.). (2017). Manual Iberoamericano de Indicadores de Vinculación de la Universidad con el Entorno Socioeconómico. Manual de Valencia. Valencia: Observatorio Iberoamericano de la Ciencia, la Tecnología y la Sociedad, Red Iberoamericana de Indicadores de Ciencia y Tecnología.

CHASE-DUNN, C. (1998). Global Formation. Structures of the World-Economy, Updated Edition. Oxford: Rowman \& Littlefield Publishing.

CORCORAN, J., ENGLANDER, K., \& MURESAN, L-M. (2019). Diverse Global Perspectives on Scholarly Writing for Publication. In: Corcoran, J., Englander, K., \& Muresan, L-M. (eds.). Pedagogies and Policies for Publishing Research in English: Local Initiatives Supporting International Scholars. London/New York: Routledge, pp. 1-16.

CURRY, M. J., \& LILLIS, T. (2014). Strategies and tactics in academic knowledge production by multilingual scholars. Education Policy Analysis Archives, vol. 22. https://doi.org/10.14507/epaa.v22n32.2014

CURRY, M. J., \& LILLIS, T. (2017). Problematizing English as the privileged language of global academic publishing. In: Curry, M. J. \& Lillis, T. (eds.), Global academic publishing: Policies, perspectives and pedagogies. Bristol: Multilingual Matters, pp. 1-22.

DE SOUSA SANTOS, B. (1985). Estado e sociedade na semiperiferia do sistema mundial: o caso português. Análise Social, n²1, pp. 869-901

DELVENNE, P. \& KREIMER, P. (2017). World-system Analysis 2.0. Globalized science in centres and peripheries. In: Tyfield, D., Lave, R., Randalls, S., \& Thorpe, C. (eds.). Handbook of the Political Economy of Science. New York: Routledge, pp. $390-404$.

ENGLANDER, K. (2014). Writing and Publishing Science Research Papers in English: A Global Perspective. Toronto: Springer Science \& Business Media. https://doi.org/10.1007/978-94-007-7714-9

FISCHMAN, G., ALPERIN, J. P., \& WILLINSKY, J. (2010). Visibility and Quality in Spanish-Language Latin American Scholarly Publishing. Information Technologies \& International Development, vol. 6, n 4, pp. 1-21.

FLOWERDEW, J. (2007). The non-Anglophone scholar on the periphery of scholarly publication. AILA Review, vol. 20, pp. 14-17. https://doi.org/10.1075/aila.20.04flo

GORDIN, M. (2015). Scientific Babel: How Science Was Done Before and After Global English. Chicago: Chicago University Press. https:// doi.org/10.7208/chicago/9780226000329.001.0001

GRUBER, T. (2014). Academic sell-out: how an obsession with metrics and rankings is damaging academia. Journal of Marketing for Higher Education, vol. 24, nº 2, pp. 165-177. https://doi.org/10.1080/08841241.2014.970248

HAMEL, R. E. (2013). El campo de las ciencias y la educación superior entre el monopolio del inglés y el plurilingüismo: elementos para una política del lenguaje en América Latina. Trabalhos em Linguística Aplicada, vol. 52, n 2, pp. 321-384. https://doi.org/10.1590/S0103-18132013000200008

HANAUER, D., SHERIDAN, C., \& ENGLANDER, K. (2019). Linguistic Injustice in the Writing of Research Articles in English as a Second Language: Data from Taiwanese and Mexican Researchers. Written Communication, vol. 36, $\mathrm{n}^{\circ} 1, \mathrm{pp}$. 136-154. https://doi.org/10.1177/0741088318804821

HARAWAY, D. (2004). Situated knowledges: the science question in feminism and the privilege of partial perspective. In: Harding, S. (ed.), The Feminist Standpoint Theory Reader: Intellectual and Political Controversies. New York: Routledge, pp. 81-101. 
HARDING, S. (2008). Sciences from below. Feminisms, Postcolonialities, and Modernities. Durham: Duke University Press.

HULTGREN, A. K. (2019). English as the Language for Academic Publication: on Equity, Disadvantage and 'Non-Nativeness' as a Red Herring. Publications, vol. 7, n² 2. https://doi.org/10.3390/publications7020031

JARAMILLO, H., LUGONES, G., \& SALAZAR, M. (eds.) (2001). Normalización de Indicadores de Innovación Tecnológica en América Latina y el Caribe - Manual de Bogotá. Bogotá: Red Iberoamericana de Indicadores de Ciencia y Tecnología, Organización de Estados Americanos, CyTED, COLCIENCIAS, OCyT.

KREIMER, P. (2019). Science and Society in Latin America: Peripheral Modernities. New York: Routledge.

LILLIS, T., HEWINGS, A., VLADIMIROU, D., \& CURRY, M. J. (2010). The geolinguistics of English as an academic lingua franca: citation practices across English-medium national and English-medium international journals. International Journal of Applied Linguistics, vol. 20, n 1, pp. 111-135. https://doi.org/10.1111/j.1473-4192.2009.00233.x

LUGONES, G., SUÁREZ, D., \& DE ALMEIDA ALVES, N. (coords.) (2009). Lisbon Manual, Guidelines for interpretation of available statistical data and construction of indicators for Ibero-America's transition to the Information Society. Lisbon: Red Iberoamericana de Indicadores de Ciencia y Tecnología, Organización de Estados Iberoamericanos para la Educación, la Ciencia y la Cultura, Ministry of Education of Portugal.

MONTEIRO, K. \& HIRANO, E. (2020). A periphery inside a semi-periphery: The uneven participation of Brazilian scholars in the international community. English for Specific Purposes, vol. 58, pp. 15-29. https://doi.org/10.1016/j.esp.2019.11.001

MORENO FERNÁNDEZ, A., REY-ROCHA, J., BURGESS, S., LÓPEZ-NAVARRO, I., \& SACHDEV, I. (2012). Spanish researchers' perceived difficulty writing research articles for English medium journals: the impact of proficiency in English versus publication experience. Ibérica, ${ }^{\circ} 24$, pp. 157-184.

O’NEILL, D. (2018). English as the lingua franca of international publishing. World Englishes, vol. 37, n 2, pp. 146-165. DOI http://doi.wiley.com/10.1111/weng. 12293

ORGANISATION FOR ECONOMIC CO-OPERATION AND DEVELOPMENT (2020). Main Science and Technology Indicators, Volume 2019 Issue 2. Paris: OECD Publishing. https://doi.org/10.1787/g2g9ff07-en

ORTIZ, R. (1997). Mundialización y cultura. Buenos Aires: Alianza Editorial.

ORTIZ, R. (2009). La supremacía del inglés en las ciencias sociales. Buenos Aires: Siglo XXI Editores.

POLINO, C., \& CASTELFRANCHI, Y. (coords.) (2015). Manual de Antigua: indicadores de percepción pública de la ciencia y la tecnología. Buenos Aires: Red Iberoamericana de Indicadores de Ciencia y Tecnología.

RED DE INDICADORES DE CIENCIA Y TECNOLOGÍA IBEROAMERICANA E INTERAMERICANA (2019). El estado de la ciencia, principales indicadores de ciencia y tecnología iberoamericanos / interamericanos 2019. Buenos Aires: Red Iberoamericana de Indicadores de Ciencia y Tecnología.

SALAGER-MEYER, F. (2014). Writing and publishing in peripheral scholarly journals: How to enhance the global influence of multilingual scholars? Journal of English for Academic Purposes, vol. 13, pp. 78-82. https://doi.org/10.1016/j.jeap.2013.11.003

SALAGER-MEYER, F. (2015). Peripheral scholarly journals: From locality to globality. Ibérica, vol. 30, pp. 15-36.

SALATINO, M. (2018). La estructura del espacio latinoamericano de revistas científicas. Tesis de doctorado en Ciencias Sociales, Facultad de Ciencias Políticas y Sociales, Universidad Nacional de Cuyo, Mendoza, Argentina.

SALÖ, L. (2015). The linguistic sense of placement: Habitus and the entextualization of translingual practices in Swedish academia. Journal of Sociolinguistics, vol. 19, n 4, pp. 511-534. https://doi.org/10.1111/josl.12147

SOlOVOVA, O., SANTOS, J. \& VERÍSSIMO, J. (2018). Publish in English or Perish in Portuguese: Struggles and Constraints on the Semiperiphery. Publications, vol. 6, n 2. https://doi.org/10.3390/publications6020025 
VESSURI, H. (2013). The dynamics of transformation processes in global social knowledge. In: Kuhn, M., Okamoto, K. (eds.). Spatial social thoughts in global knowledge encounters. Stuttgart: Ibidem, pp. 263-284.

VESSURI, H., GUÉDON, J-C., \& CETTO, A. M. (2014). Excellence or quality? Impact of the current competition regime on science and scientific publishing in Latin America and its implications for development. Current Sociology, vol. 62, $\mathrm{n}^{\circ}$ 5, pp. 647-665. https://doi.org/10.1177/0011392113512839

VIKØR, L. (2004). Lingua Franca and International Language / Verkehrssprache und Internationale Sprache. In: Ammon, U., Dittmar, N., Mattheier, K. \& Trudgill, P. (eds.). Sociolinguistics: An International Handbook of the Science of Language and Society, $2^{\text {nd }}$ ed. Berlin: De Gruyter, pp. 328-335.

WALLERSTEIN, I. (2004). World-Systems Analysis: An Introduction. Durham: Duke University Press.

Recebido: $11 / 6 / 2020$

Aceito: $13 / 12 / 2020$

Publicado: 3/3/2021 